\title{
Assessment of seismic response of a soil layer with the oscillating inclusions
}

\author{
O.V. Kendzera, S.V. Mykulyak, Yu.V. Semenova, I.A. Skurativska, \\ S.I. Skurativskyi, 2020
}

S.I. Subbotin Institute of Geophysics, National Academy of Sciences of Ukraine, Kiev, Ukraine

Received 25 May 2020

\begin{abstract}
The results of modern studies of the earthquakes impact indicate that the soil layers located under buildings and structures can significantly transform seismic wave passing through their thickness and have a catastrophic effect on these objects. Hence, the study of wave processes in soil massifs is extremely important and relevant. It is known that soils are characterized by significant heterogeneity, which affects the spectral characteristics of seismic waves, so this should be taken into account when analyzing wave fields in the soil layers. In this paper, it is proposed to describe the dynamics of an inhomogeneous soil massif within the model of an elastic continuum with oscillating non-interacting dissipative inclusions. To examine vibrations in the layer of finite thickness with a free surface and harmonic perturbation applied to its lower edge, it is formulated the boundary value problem for this medium. Based on the solution of this problem, the influence of inclusions on the characteristics of waves is analyzed. It is found out that the natural frequency of inclusions significantly affects the transfer function, which characterizes the amplification of the displacements on the free surface relative to the displacements at the lower boundary of the layer, i. e. when the natural frequency of inclusions increases, near the leading resonant peak additional resonant frequency appears, while for high frequencies a degeneration of resonant frequencies is observed. In the case when the natural frequencies of the inclusions have a non-discrete distribution with two separate frequencies, the effect of the inclusions is manifested at low-frequency oscillations, and in the high-frequency region only the resonant amplitude decreases. The approach, which uses the model with oscillating inclusions to the analysis of layer response to seismic disturbances, is promising for seismic design and construction.
\end{abstract}

Key words: amplitude-frequency characteristics, resonant phenomena, models of heterogeneous media, ground response modeling to seismic load.

Introduction. Analysis of seismic effects of earthquakes (degree and regularity of damage to buildings) allowed one to conclude that the intensity of oscillations and subsequent damage to weakly consolidated soils may significantly exceed these parameters in neighboring regions, such as those composed of dense rocks. Depending on the type, composition and thickness of the soil layers, oscillations at some frequencies may be amplified, while at other frequencies they may be suppressed or even completely absorbed. When the frequency of soil oscillations coincides with the natural frequency of buildings, resonant phenomena are detected, which are the most common causes of damage to buildings [Pratt et al., 2017]. Assessment of the impact of local soil conditions in the region on the seismic intensity distribution is 
the main problem of seismic microzoning [Aleshin, 2010]. Despite the large number of works in this field of research, the problem of adequate prediction of soil behavior under seismic loads remains one of the most pressing challenges of seismology. First of all, this is due to insufficient study of the mechanism of influence of physical and mechanical soil properties on the deformation under seismic loading and dynamic properties that characterize the soil as a medium for the propagation of oscillations.

Evidence that seismic action is affected by soil conditions rather than the magnitude or energy of an earthquake is the aftermath of the 1925 Quebec earthquake in the Lawrence Valley, Canada. The most serious damage and destruction of buildings was recorded at a distance of more than $100 \mathrm{~km}$ from the source of the earthquake. Note that the buildings were located on the loose sediments of the St. Charles River. The damage inspection revealed that the steel structures of the granary were bent, the concrete floors were torn down, and the foundations of the reinforced concrete columns were destroyed. At the same time, at a distance of about $800 \mathrm{~m}$ from the epicenter of the earthquake, residents of a large hotel built on a rocky slope, almost did not feel the earthquake. The local intensity on loose sediments was 8 points, and on rocky soils - 3 points according to the Modified Mercalli Intensity Scale [Smith, 1962]. Thus, the difference in the behavior of structures due to soil conditions reached 5 points.

At the initial stage of research on the seismic effects of earthquakes, the influence of physical and mechanical properties of the soil on the intensity of earthquake manifestations was underestimated [Bovenko, Dontsova, 1987; Khalturin et al., 1990]. These works used a simplified approach (differentiation of soils by their seismic properties) and obviously required further improvement.

The problem of amplification of seismic signals is the main task of the ground respond analysis [Kramer, 1996; Wolf, 1985]. It has been studied by various quantitative methods, including the technique of transfer functions based on the linear concept of elastic soil [Kramer, 1996; Gazetas, 1982; Rezaie et al., 2018; Kendzera et al., 2020]; equivalent linear approximation as the simplest generalization of a purely linear approach; a nonlinear approach [Kausel, Roësset, 1984] using nonlinear stress-strain relationships; multidimensional generalizations of the above methods, etc.

Nowdays, modeling methods are used to solve the problems of predicting soil behavior during an earthquake [Kramer, 1996; Yoshida, 2015; Kokusho, 2017], which are based on the approximation of real soils by mathematical models that take into account the structural properties of soils and patterns of their behavior under seismic loading. Predicting soil behavior during an earthquake is complicated by insufficient knowledge of soil properties under seismic loading.

The purpose of the work is a theoretical estimation of the amplitude-frequency characteristics of an inhomogeneous soil layer with oscillating inclusions under seismic loading on its base. Particular attention is paid to identifying the effects caused by taking into account the dynamics of inhomogeneities.

Mathematical model of the soil taking into account the oscillatory dynamics of inclusions. During modeling wave processes in the layer of heterogeneous elastic medium [Kendzera et al., 2020], the dynamic equation of state with temporal and spatial nonlocalities was used. This generalized model allows one to describe the dynamical properties of structured media taking into account the correlation between the elements of the structure, as well as the phenomena of self-organization [Danylenko et al., 2011].

Another technique to the medium's structure description is based on the incorporation of additional volumetric forces, caused by structural element movement, in the equations of motion. Among the models of this approach, it is worth to indicate the models of moment continuum theories [Cosserat, Cosserat, 1909; Green, Rivlin, 1964; Mindlin, 1964; Nowacki, 
1970, 1986; Eringen, 1999; Erofeev, 2003; Maugin, Metrikine, 2010]. In the continual approach, these theories take into account the asymmetry of the stress tensor and describe the auxiliary degrees of freedom of the generalized microvolume of the medium. It is noteworthy that these degrees of freedom are associated with deformations and rotations of microstructural elements.

In this research we are interested in the model for a heterogeneous medium representing the soil as a structure in which heterogeneity is formed by different inclusions distributed in carrying uniform medium. It is considered the inclusions which interact with carrying medium only and do not interact with each other. It is assumed that these inclusions form an auxiliary quasi-continuum that interacts with the carrying classical continuum. Such models for media with inclusions have been developed by a number of experts to search the peculiarities of wave fields in natural and artificial materials with microstructure [Slepjan, 1967; Palmov, 1998; Milton, Willis, 2007; Mishuris et al., 2019]. The detailed studies of features of wave fields at different properties of carrying medium and inclusions have been carried out by V.A. Danylenko and S. I. Skurativskyi in a number of works [Danilenko, Skurativskyi, 2008, 2012a, b, 2016, 2017; Skurativsky, 2014; Skurativskyi, Skurativska, 2018; Skurativskyi et al., 2019].

Based on the basic principles of continuum theory, we postulate that the model of elastic medium with inclusions [Palmov, 1998; Danilenko, Skurativskyi, 2008, 2012a, b] consists of an infinite number of inclusions. In wave processes, they behave like oscillators. Their size $l$ is much smaller than the characteristic size of the problem $l<<L$, as well as the wavelength $l<<\lambda^{*}$. Each inclusion as a separate oscillator is characterized by the natural frequency $\Omega$, relaxation time $\tau$, and moves under acting the force depending on the difference of displacements between carrying medium and oscillator. The structure of quasicontinuum is characterized by the distribution $m(\Omega)$ of oscillators with respect to the natural frequency $\Omega$. It is obvious that the total mass of oscillators $m_{\delta V}$ placed in microvolume $\delta V$ is evaluated by integration over all natural frequencies of the oscillators

$$
m_{\delta V}=\rho \int_{0}^{\infty} m(\Omega) \delta V d \Omega,
$$

where $\rho$ is the carrying medium density.

Then the equation of motion for the carrying medium coincides with the well- known Lame equation of classical elastic theory enriched by the inclusions [Palmov, 1998]:

$$
(\lambda+2 \mu) \nabla \nabla \mathbf{u}+\mu \Delta \mathbf{u}-\rho \mathbf{u}_{t t}+\mathbf{N}+\mathbf{Q}=0,
$$

where $\mathbf{N}$ is the force acting on the medium from the inclusions, $\mathbf{Q}$ is the external mass force, $\lambda$ and $\mu$ are the Lame constants. The equation of motion for inclusions with natural frequency $\Omega$ reads as follows

$$
\rho m(\Omega) \mathbf{w}_{t t}+K(\Omega)(\mathbf{w}-\mathbf{u})+K(\Omega) \tau \cdot(\mathbf{w}-\mathbf{u})_{t}=0 .
$$

Here $\mathbf{w}$ is the inclusion displacement, $K(\Omega)$ is the stiffness of bond between the inclusion and carrying material. The last add in equation (3) is associated with the description of dissipation of oscillator energy. The total force $\mathbf{N}$ of interaction of inclusion and carrying medium per unit volume is evaluated by the relation

$$
\mathbf{N}=-\rho \int_{0}^{\infty} m(\Omega) \mathbf{w}_{t t} d \Omega .
$$

After substitution (4) into equation (2), the equation of motion for carrying medium can be written in the following form 


$$
(\lambda+2 \mu) \nabla \nabla \mathbf{u}+\mu \Delta \mathbf{u}-\rho \mathbf{u}_{t t}-\rho \int_{0}^{\infty} m(\Omega) \mathbf{w}_{t t} d \Omega+\mathbf{Q}=0
$$

Thus, the system of equations (3) and (5) together with appropriate boundary conditions describes the dynamics of elastic continuum with oscillating dissipative inclusions.

Statement of the boundary value problem for the soil layer and analysis of its solutions. As in our previous work [Kendzera et al., 2020], we consider the simplest one-dimensional problem on the wave shear deformation which is the most dangerous for the buildings and constructions. A layer of soil with density $\rho$ and thickness $H$ lies on a rigid badrock and has a free surface. Let us introduce the reference frame $(u, z)$ with the origin placed on the free surface (Fig. 1).

For the one-dimensional shear deformation the system of equations (3), (5) is as follows

$$
\rho u_{t t}=G u_{z z}-\rho \int_{0}^{\infty} m(\Omega) w_{t t} d \Omega, \quad w_{t t}+\Omega^{2}(w-u)+\Omega^{2} \tau(w-u)_{t}=0 .
$$

Here $u(z, t)$ and $w(z, t)$ are the horizontal displacements of carrying medium and attached oscillator respectively, and $G=\mu$ is the shear modulus. The relation $\Omega^{2}=K(\Omega) / \rho m(\Omega)$ is used. In general, it should be assumed that each type of oscillator has a unique value of the relaxation time, but to obtain quite general conclusions, it is sufficient to assume the same relaxation time $\tau$, which is constant for all oscillators. We also neglect the external volumetric forces $(\boldsymbol{Q}=0)$, in particular the gravity force. To identify the function $m(\Omega)$ describing the distribution of oscillators over their natural frequencies, the following laws are used:

$$
-m(\Omega)=\sum_{j=1}^{n} M_{j} \delta\left(\Omega-\Omega_{j}\right), \text { where } \delta(\bullet) \text { is the Dirac delta function; }
$$

- continuous $n$-modal distribution:

$$
m(\Omega)=\sum_{j=1}^{n} \frac{M_{j}}{\sigma_{j} \sqrt{2 \pi}} \exp \left(-\frac{\left(\Omega-\Omega_{j}\right)^{2}}{2 \sigma_{j}^{2}}\right)
$$

It should be noted that in the case of delta distribution, model (6) has no integral term and is reduced to the model with oscillators that are distributed over their natural frequencies discretely. The multimodal distribution can be regarded as the sequence of functions converging to the Dirac delta function. This allows one to compare the results of studies of models with continuous and discrete distribution of oscillators.

The boundary conditions are prescribed at the free surface that requires the absence of stresses

$$
\left.G u_{z}\right|_{z=0}=0 \text {. }
$$

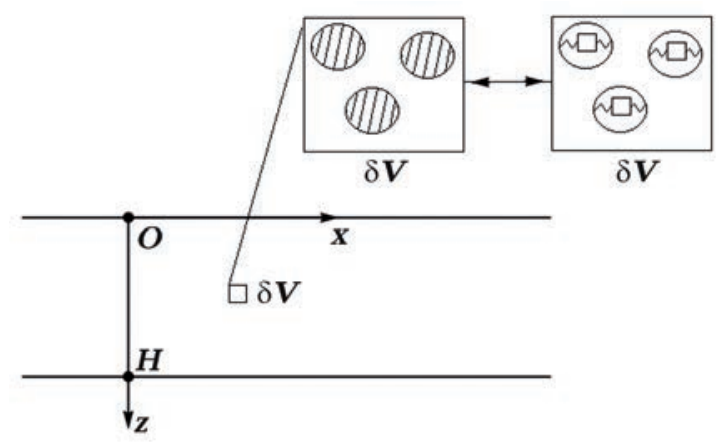

Fig. 1. Schematic representation of the soil layer with thickness of $H$ with inclusions. The left upper inset stands for the microvolume $\delta V$ with inclusions, whereas right one shows the microvolume $\delta V$ with their model analogy-oscillators. 
Thus, the aim of the studies is to examine the properties of the solutions of system (6) subjected to the boundary condition (7).

Consider the solutions of model (6) in the form of standing waves defined by the expressions harmonic in time

$$
u=U(z) e^{i \omega t}, \quad w=W(z) e^{i \omega t},
$$

where $\omega$ is the circular frequency of ground vibration.

The substitution of expressions (8) into the system (6) reduces it to pair of ordinary differential equations

$$
\begin{gathered}
-\rho U(z) \omega^{2}=G U_{z z}(z)+\rho W(z) \int_{0}^{\infty} m(\Omega) \omega^{2} d \Omega, \\
-W(z) \omega^{2}+\Omega^{2}(W(z)-U(z))+\Omega^{2} \tau(W(z)-U(z)) i \omega=0,
\end{gathered}
$$

which in turn reduces to quadrature

$$
W=\frac{\left(\Omega^{2}+\Omega^{2} \tau i \omega\right) U}{\Omega^{2} \tau i \omega+\Omega^{2}-\omega^{2}}
$$

and the following second order differential equation

$$
\rho \omega^{2} U+G U_{z z}+\rho \omega^{2} U \int_{0}^{\infty} m(\Omega) \frac{\Omega^{2}(1+\tau i \omega)}{\Omega^{2}(1+\tau i \omega)-\omega^{2}} d \Omega=0 .
$$

It is useful to rewrite this equation as follows

$$
U_{z z}+v^{2} U=0
$$

where $v^{2}=\frac{\rho}{G} \omega^{2}\left(1+\int_{0}^{\infty} \frac{m(\Omega) \Omega^{2}(1+\tau i \omega)}{\Omega^{2}(1+\tau i \omega)-\omega^{2}} d \Omega\right)$.

The solution of equation (9) is presented in the well-known form:

$$
U=A \cos v z+B \sin v z \text {. }
$$

The constants $A$ and $B$ can be specified from the boundary condition (7). Then $B=0$, and ultimately $u(z, t)=A e^{i \omega t} \cos v z$.

To characterize the wave passing through the soil deposit, it is used the quantity called the transfer function [Kramer, 1996]

$$
F=\frac{u(z=0 ; t)}{u(z=H ; t)}
$$

where $u(z=H ; t)$ is the deformation at the depth $H$. The modulus of this function $|F|$ is the amplification factor [Kramer, 1996]. It should be emphasized that when deformations at the layer edges are defined by standing waves, then the function $F$ is independent on the time. In particular, in our considerations

$$
F=\frac{1}{\cos \Omega H}
$$


Formally, it coincides with the transfer function derived for the Kelvin-Voight models from [Kramer, 1996].

Let $v_{s}=\sqrt{\frac{G}{c}}$ be the shear wave velocity. Then

$$
v H=\omega \frac{H}{v_{s}} \sqrt{1+(1+\tau i \omega) \int_{0}^{\infty} \frac{\Omega^{2} m(\Omega)}{\Omega^{2}(1+\tau i \omega)-\omega^{2}} d \Omega} .
$$

Hence, the amplification factor is

$$
|F|=\frac{1}{\left|\cos \omega \frac{H}{v_{s}} \sqrt{1+(1+\tau i \omega) \int_{0}^{\infty} \frac{\Omega^{2} m(\Omega)}{\Omega^{2}(1+\tau i \omega)-\omega^{2}} d \Omega}\right|} .
$$

Remark 1. Note that the argument of function $|F|$ cannot be written via the quantity $k H(k=$ $=\omega / v_{s}$ is the wave number) the way this is done in classical models [Kramer, 1996]. Therefore, the function $|F|$ will be studied directly with respect to the argument $\omega$. Moreover, the quantities with time dimension $H / v_{s}=\chi$ (time of passing the shear wave through the layer) and $\tau$ (time of relaxation) can represent the characteristic parameters of soil layer and medium.

Remark 2. The number of parameters in the function $|F|$ can be reduced by means of scale transformation $\omega \chi=\bar{\omega}, \Omega \chi=\bar{\Omega}, \tau / \chi=\bar{\tau}$, where new quantities $\bar{\omega}, \bar{\Omega}$ and $\bar{\tau}$ are dimensionless. Then

$$
\cos \omega \chi \sqrt{1+(1+\tau i \omega) \int_{0}^{\infty} \frac{\Omega^{2} m(\Omega)}{\Omega^{2}(1+\tau i \omega)-\omega^{2}} d \Omega}=\cos \bar{\omega} \sqrt{1+(1+\bar{\tau} i \bar{\omega}) \int_{0}^{\infty} \frac{\bar{\Omega}^{2} \overline{m(\Omega)}}{\bar{\Omega}^{2}(1+\bar{\tau} i \bar{\omega})-\bar{\omega}^{2}} d \bar{\Omega}}
$$

and the function $\overline{m(\Omega)}=\frac{1}{\chi} m\left(\frac{\bar{\Omega}}{\chi}\right)$. For instance, in case of the Gaussian distribution it is valid

$$
\overline{m(\Omega)}=\frac{1}{\chi} m\left(\frac{\bar{\Omega}}{\chi}\right)=\frac{M_{1}}{\chi \sigma_{1} \sqrt{2 \pi}} \exp \left(-\frac{\left(\bar{\Omega}-\chi \Omega_{1}\right)^{2}}{2 \chi^{2} \sigma_{1}^{2}}\right) .
$$

From the last expression it follows that $\overline{m(\Omega)}$ represents the distribution with the scaled mean value $\chi \Omega_{1}$ and standard deviation $\chi \sigma_{1}$. This means that the solution of the problem at different values $\chi$ can be obtained from the solution derived at $\chi=1$ performing in parallel the appropriate scaling of distribution parameters. Therefore, further we consider the problem at $\chi=1$. The amplification factor obeys the relation

$$
|F|=\frac{1}{\left|\cos \omega \sqrt{1+(1+\tau i \omega) \int_{0}^{\infty} \frac{\Omega^{2} m(\Omega)}{\Omega^{2}(1+\tau i \omega)-\omega^{2}} d \Omega}\right|} .
$$


Let us find out the peculiarities appearing on the graphs of function (10) when oscillating inclusions are taken into account. To compare, it is worth to recall the fact when the heterogeneity is absent, i. e. $m(\Omega)=0$, the function (10) degenerates into the function $|F|=\frac{1}{|\cos \omega|}$ whose graph (Fig. 2, a) shows the periodically located maxima

$$
\omega_{n}=\frac{\pi}{2}(2 n+1), \quad n=0,1,2 \ldots,
$$

which determine the natural frequencies of the soil layer providing the most strong response amplification, i. e. the occurrence of resonance. Note that a distinction should be made between the three types of frequencies used in this paper, namely natural frequencies of inclusions, circular frequencies of standing waves, and natural frequencies of soil deposit. To avoid misunderstandings, we prefer to use the term "resonant frequency» instead of the latter term.

Since the model does not include viscosity effects at $m(\Omega)=0$, the function $|F(\omega)|$ at resonant frequencies has the discontinuities of second kind. The introduction of the dissipative process generates finite maxima on the graph of the function $|F(\omega)|$. The structure of resonant frequencies, their number, and intensity are of both theoretical and practical interest. Next it is considered the cases when the function $m(\Omega) \neq 0$.

The medium with identical oscillators. Let the soil contain inclusions having the same natural frequency $\Omega_{1}$. Then the inclusion distribution is $m(\Omega)=M_{1} \delta\left(\Omega-\Omega_{1}\right)$ and the amplification factor is as follows

$$
|F|=\frac{1}{\left|\cos \omega \sqrt{1+\frac{\Omega_{1}^{2}(1+\tau i \omega) M_{1}}{\Omega_{1}^{2}(1+\tau i \omega)-\omega^{2}}}\right|} .
$$

We choose the parameter $M_{1}=1.2$ corresponding to the inclusions with density greater than the carrying medium. The natural frequency of oscillators is fixed as well, i. e. $\Omega_{1}=1$. The resulting graph of the function $|F|$ defined by (12) is depicted in Fig. $2, b$.

To analyze the function (12) in details, we need to pass from complex-valued to a real-
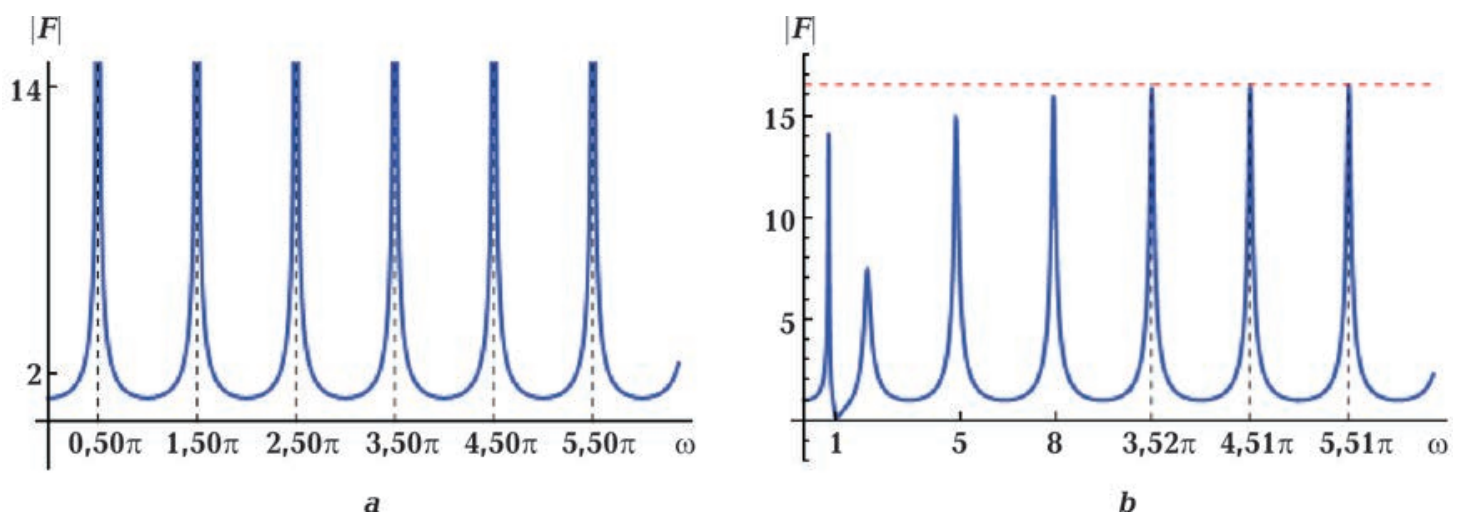

Fig. 2. The amplification factor $|F|$ versus $\omega$ at $m=0(a), m=1.2(b)$. 
valued function. Let

$$
x=\omega, \quad a=1+\frac{m\left(1-\left(x / \Omega_{1}\right)^{2}+\tau^{2} x^{2}\right)}{\left(1-\left(x / \Omega_{1}\right)^{2}\right)^{2}+(\tau x)^{2}}, \quad b=-\frac{m \tau x^{3} / \Omega_{1}^{2}}{\left(1-\left(x / \Omega_{1}\right)^{2}\right)^{2}+(\tau x)^{2}} .
$$

Using the formula

$$
\sqrt{a+b i}= \pm\left(\sqrt{\frac{|q|+a}{2}}+i \operatorname{sgn}(b) \sqrt{\frac{|q|-a}{2}}\right),|q|=\sqrt{a^{2}+b^{2}}
$$

the denominator of (12) can be transformed in the following manner

$$
\cos (\bullet)=\cos \left(x a_{1}-i x b_{1}\right)
$$

where $a_{1}=\sqrt{\frac{|q|+a}{2}}, b_{1}=\sqrt{\frac{|q|-a}{2}}$.

Taking into account that $|\cos (x-i y)|=\sqrt{\cos ^{2} x+\sinh ^{2} y}$, the expression (12) can be presented in the simplified form

$$
|F|=\frac{1}{\sqrt{\cos ^{2}\left(x a_{1}\right)+\sinh ^{2}\left(x b_{1}\right)}} .
$$

From the analysis of expressions $a$ and $b$ it follows that for large values of $x$ these quantities tend to 1 and 0 respectively, thus $a_{1} \rightarrow 1, b_{1} \rightarrow 0$. This means that at high frequencies the resonant frequencies approach the set (11) and hence it can be stated that the presence of inclusions in the medium is not manifested.

The increasing of natural frequency $\Omega_{1}$ causes a change of graph of the function $|F|$ mainly in the vicinity of the first resonant frequencies (Fig. 3, a). In particular, the comparison of the
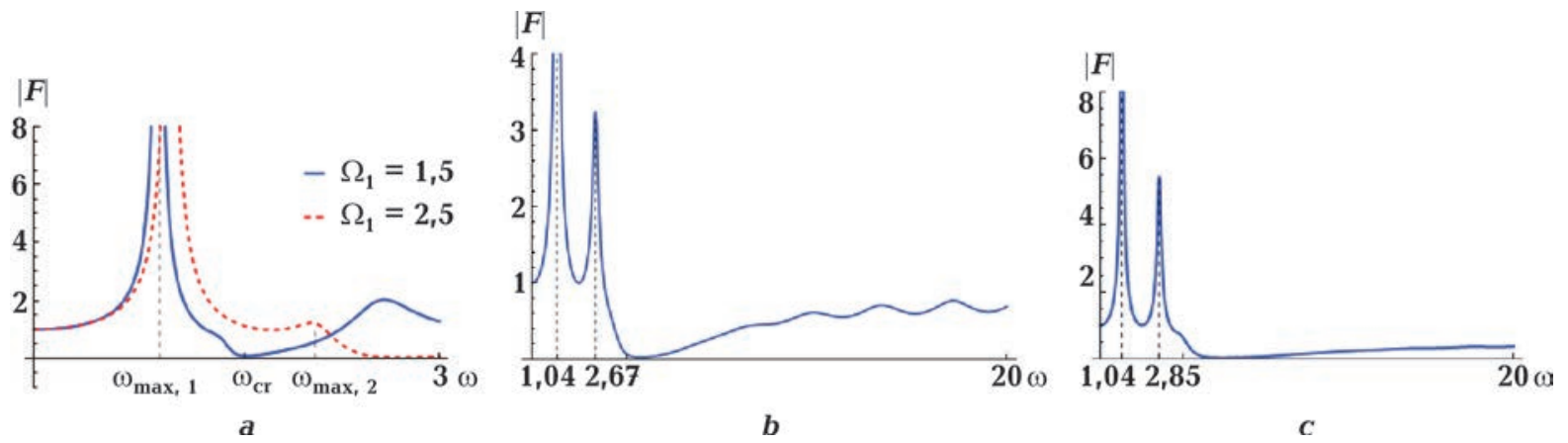

Fig. 3. The dependencies of amplification factor $|F|$ on $\omega$ at $m=1.2, \tau=0.1$ and $\Omega_{1}=1.5, \Omega_{1}=2.5(a)$, $\Omega_{1}=4(b), \Omega_{1}=5(c)$. 
graphs built at $\Omega_{1}=1.5$ and $\Omega_{1}=2.5$ reveals the creation of additional resonant frequency $\omega_{\max , 2}$ near the leading resonant peak $\omega_{\max , 1}$. Analysis of resonant spectra for higher natural frequencies $\Omega_{1}$ testifies that intensity of second resonant peak $\omega_{\max , 2}$ increases, and the set of resonant frequencies in the high-frequency region degenerates. In particular, comparing the Fig. $3, b$ and $c$, we can conclude that the oscillatory asymptotics of the function $|F|$ is changed to the monotonic one. In fact, there is case when the spectrum is divided into the low-frequency region consisting of a finite number of resonant frequencies and the high-frequency region with a countable set of resonant peaks that tend to degeneration when the natural frequency of inclusions increases. Here, as a point of spectrum division, we can choose the place of the global minimum of the function $|F(\omega)|$, i. e. the point $\omega_{c r}$.

It is interesting that the dependence (Fig. 4) of the coordinates of the first two resonant peaks $\omega_{\max , 1,2}$ on the parameter $\Omega_{1}$ shows a monotonic nonlinear character. Note that the relative change $\omega_{\max , 1}$ is $4.3 \%$, while for $\omega_{\max , 2}$ is $39.1 \%$.

The dependence of the value of the critical frequency $\omega_{c r}$ on the parameter $M_{1}$ (Fig. 5) is monotonic and has a local minimum.

Media with oscillators of two types. First of all, it should be noted that regardless of the analytical expression of the function $m(\Omega)$, the behavior of the function $|F|$ can be estimated for relatively large values $\omega$. To do this, let us expand part of the function under integral sign
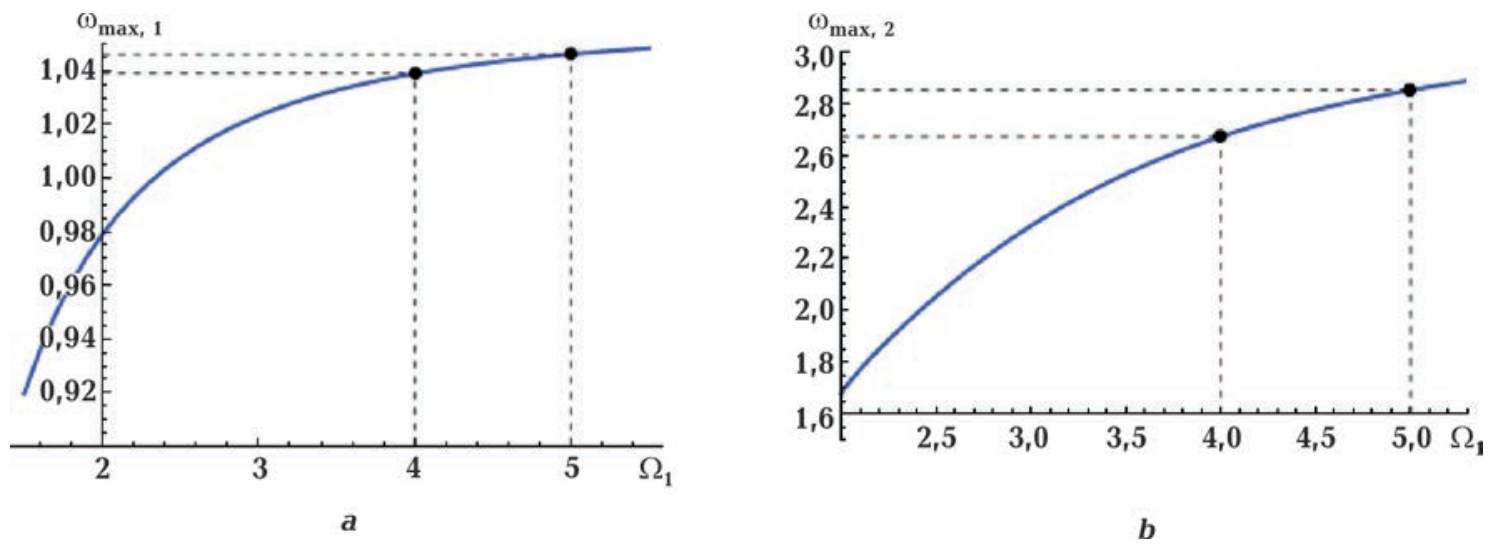

Fig. 4. The dependencies of the first ( $a$ ) and second (b) maxima $\omega_{\max , 1,2}$ on the natural frequency $\Omega_{1}$.

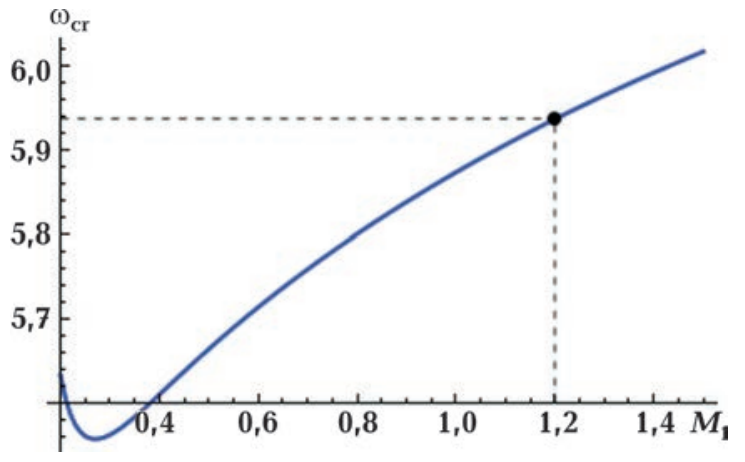

Fig. 5. The global minimum $\omega_{c r}$ versus $M_{1}$. into the Taylor series (or to use a formula for infinite geometric progression). Then we get

$$
\begin{aligned}
\frac{\Omega^{2}}{\Omega^{2}(1+\tau i \omega)-\omega^{2}} & =-\frac{\Omega^{2}}{\omega^{2}}-\frac{(1+\tau i \omega) \Omega^{4}}{\omega^{4}}+ \\
+ & O\left(\Omega^{6}\right),
\end{aligned}
$$

when $\omega>\Omega$.

Thus 


$$
\begin{gathered}
(1+\tau i \omega) \int_{0}^{\infty} \frac{\Omega^{2} m(\Omega)}{\Omega^{2}(1+\tau i \omega)-\omega^{2}} d \Omega=-\int_{0}^{\infty} \frac{(1+\tau i \omega) \Omega^{2} m(\Omega)}{\omega^{2}} d \Omega-\int_{0}^{\infty} \frac{(1+\tau i \omega)^{2} \Omega^{4} m(\Omega)}{\omega^{4}} d \Omega= \\
=-\frac{(1+\tau i \omega)}{\omega^{2}} I_{2}-\frac{(1+\tau i \omega)^{2}}{\omega^{4}} I_{4} .
\end{gathered}
$$

Here $I_{2 n}=\int_{0}^{\infty} \Omega^{2 n} m(\Omega) d \Omega$.

Finally, we obtain the result that for large $\Omega$ the function $|F|$ can be approximated by the expression

$$
|F|=\frac{1}{\left|\cos \omega \sqrt{1-\frac{(1+\tau i \omega)}{\omega^{2}} I_{2}-\frac{(1+\tau i \omega)^{2}}{\omega^{4}} I_{4}}\right|} .
$$

In particular, it is easy to see that as $\Omega$ becomes large in (14) the positions of resonant frequencies are close to the set (11), which is valid for the classical case when the inclusions are absent.

To realize the quality of $|F|$ approximation, the result obtained is applied to the model with the two-modal distribution $m(\Omega)$.

Thus, consider the case of the medium containing the same number of inclusions of two types oscillating mainly at the natural frequencies $\Omega_{1}$ and $\Omega_{2}=2 \Omega_{1}$. Then the distribution $m(\Omega)$ of oscillators is described by the two-modal distribution

$$
m(\Omega)=\frac{M_{1}}{2 \sigma \sqrt{2 \pi}}\left(\exp \left(-\frac{\left(\Omega-\Omega_{1}\right)^{2}}{2 \sigma^{2}}\right)+\exp \left(-\frac{\left(\Omega-2 \Omega_{1}\right)^{2}}{2 \sigma^{2}}\right)\right)
$$

where $\sigma=0.1, M_{1}=1.2, \Omega_{1}=0.9$.

The distribution parameters are chosen in such a way that the oscillator masses are localized strongly in the vicinity of two fixed values (Fig. 6, a). Using the distribution (15), the Fig. $6, b$ is plotted and shows the graphs of function (10) (solid curve) and its approximation (14) (dashed curve). It is seen that as soon as the function $m(\Omega)$ goes to its right asymptotic value, the function (14) is fit for the actual function (10) very well.

Using the formula (10) and (12), the amplification factors $|F|$ corresponding to the medium with the same type inclusions and two-type inclusions are derived and plotted in Fig. 7. These dependences indicate that the influence of the inclusion characteristics is manifested in the low-frequency domain, in particular, additional maximum appeared. In high-frequency domain the decay of intensity of resonant frequencies is encountered. This means that the influence of inclusion characteristics is manifested in the low-frequency region, whereas in the high-frequency region the decreasing of resonant peak intensity is observed.

Concluding remarks. To estimate the response of the soil deposit under the action of seismic disturbances, the problem of shear wave deformation of the soil layer is considered. It is proposed to model an inhomogeneous soil massif by the elastic medium with dissipative oscillatory inclusions. The obtained harmonic solutions of the model in the form of standing 

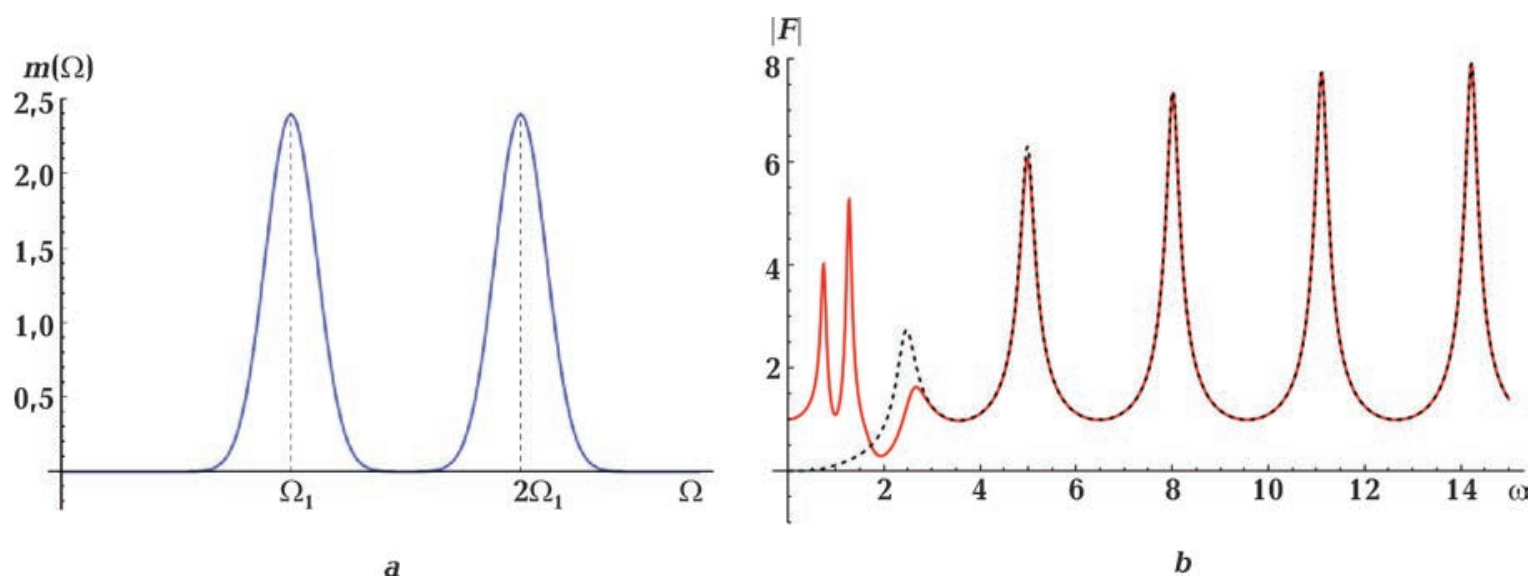

Fig. 6. The function $m(\Omega)(a)$ and the comparison of amplification factors $|F|$ derived by means of the function (10) (solid line) and (14) (dashed curve) (b).

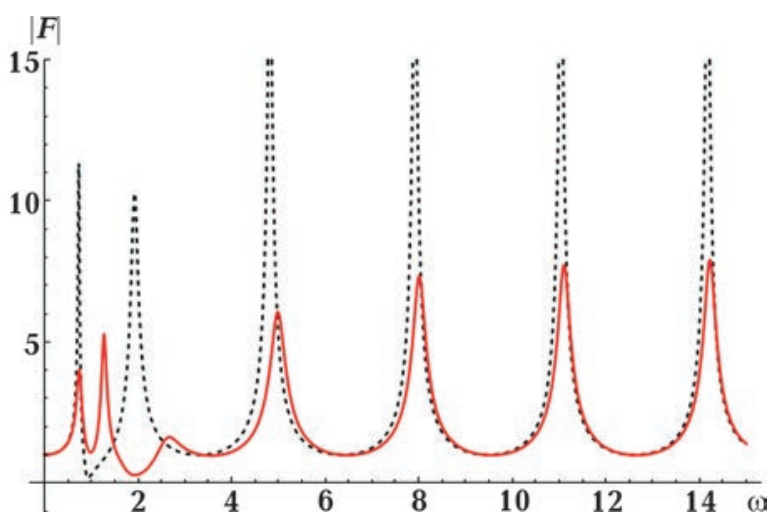

Fig. 7. The amplification factor $|F|$ versus $\omega$ for the case of one type of inclusions (dashed line) and two types of inclusions (solid curve). waves allowed us to analyze the influence of inclusions on the wave characteristics. In particular, it was found that the presence of dissipative inclusions leads to finite resonant oscillation amplitudes and, accordingly, to limited heights of resonant peaks in the transfer function, which characterizes the amplification of displacements on the free surface with respect to displacements on the lower surface of the layer. It is also shown that the natural frequency of inclusions significantly affects the properties of the transfer function: 1) when the natural frequency of inclusions increases, then the auxiliary resonant peak appears near the leading resonant frequency; 2) degeneration of resonances is observed at high circular frequencies of standing waves. When the medium incorporates two types of inclusions and, thus, the bimodal distribution is used, the structure of the resonant frequencies changes only in the low frequency domain, in the high frequency domain the intensity of the resonant peaks decreases.

These studies inspire further investigations of wave fields in the layer of the medium with inclusions, which should help to elucidate the influence of viscosity and multimodality of the distribution on it. The obtained results contribute to the improvement of methods of response to soil deposits on seismic disturbances, which provide reliable seismic protection of artificially created objects.

The work is partially supported by the project $0118 \mathrm{U} 000044$. 


\section{References}

Aleshin, A.S. (2010). Seismic microzoning of especially important objects. Moscow: Svetoch Plus, 293 p. (in Russian).

Bovenko, V.G., \& Dontsova, G.Yu. (1987). Seismic microzoning of territory of the proposed development in a low-active region. In: Engineering-seismological and geophysical studies in engineering surveys for building (pp. 23-87). Moscow: Nauka (in Russian).

Cosserat, E., \& Cosserat, F. (1909). Théorie des Corps déformables. New York: Cornell University Library, $242 \mathrm{p}$.

Danilenko, V.A., \& Skurativskyy, S.I. (2008). Resonant modes of propagation of nonlinear wave fields in media with oscillating inclusions. Dopovidi NAN Ukrayiny, (11), 108-112 (in Ukrainian).

Danylenko, V.A., Danevych, T.B., Makarenko, O.S., Vladimirov, V.A., \& Skurativskyi, S.I. (2011). Self-organization in nonlocal non-equilibrium media. Kyiv: Ed. Of S.I. Subbotin Institute of Geophysics, NAS of Ukraine, 333 p.

Danylenko, V.A., \& Skurativskyi, S.I. (2012a). Wave solutions to the model for media with Van der Pol oscillators. Dinamicheskie sistemy (Dynamical System), 2(3-4), 227-239 (in Ukrainian).

Danylenko, V.A., \& Skurativskyi, S.I. (2012b). Travelling Wave Solutions of Nonlocal Models for Media with Oscillating Inclusions. Nonlinear Dynamics and Systems Theory, (4), 365-374.

Danylenko, V.A., \& Skurativskyi, S.I. (2016). Peculiarities of wave dynamics in media with oscillating inclusions. International Journal of Nonlinear Mechanics, 84, 31-38. https://doi.org/10.1016/j. ijnonlinmec.2016.04.010.

Danylenko, V.A., \& Skurativskyi, S.I. (2017). Dynamics of Waves in the Cubically Nonlinear Model for Mutually Penetrating Continua. Discontinuity, Nonlinearity, and Complexity, 6(4), 425-433. doi:10.5890/DNC.2017.12.002.

Eringen, A.C. (1999). Microcontinuum Field Theory. Vol. I. Foundations and Solids. New York: Springer, $341 \mathrm{p}$.

Erofeev, V.I. (2003). Wave Processes in Solids with Microstructure. Singapore: World Scientific, 276 p.

Gazetas, G. (1982). Vibrational characteristics of soil deposits with variable wave velocity. International Journal for Numerical and Analytical Methods in Geomechanics, 6(1), 1-20. doi: 10.1002/ nag.1610060103.

Green, A.E., \& Rivlin, R.S. (1964). Multipolar continual mechanics. Archive for Rational Mechanics and Analysis, 17, 113-147.

Kausel, E., \& Roësset, J.M. (1984). Soil amplification: some refinements. International Journal of Soil Dynamics and Earthquake Engineering, 3(3), 116-123. https://doi.org/10.1016/0261-7277 (84)90041-X.

Kendzera, O.V., Mykulyak, S.V., Semenova, Yu.V., \& Skurativskyi, S.I. (2020). Modeling of seismic response of soil layer within the framework of nonlocal model of continuous medium. Geofizicheskiy zhurnal, 42(3), 47-58 (in Ukrainian). https://doi.org/10.24028/gzh.0203-3100.v42i3. 2020.204700 . 
Khalturin, V.I., Shomakhmadov, A.M., Gedakian, E.G. et al (1990). Enhancement of macroseismic effect in Leninakan. Technogenic factors and problems of predicting the seismic effect: Abstracts of conference dedicated to the 80th anniversary of G.A. Mavlyanova (pp. 28-30). Tashkent (in Russian).

Kokusho, T. (2017). Innovative Earthquake Soil Dynamics. CRC Press, 478 p.

Kramer, S.L. (1996). Geotechnical Earthquake Engineering. N.J., Prentice Hall, Upper Saddle River, $672 \mathrm{p}$.

Maugin, G.A., \& Metrikine, A.V. (2010). Mechanics of Generalized Continua: One Hundred Years After the Cosserats. New York: Springer, 337 p.

Milton, G.W., \& Willis, J.R. (2007). On modifications of Newton's second law and linear continuum elastodynamics. Proceedings of the Royal Society A, 463, 855-880. https://doi.org/10.1098/rspa. 2006.1795.

Mindlin, R.D. (1964). Microstructure in linear elasticity. Archive for Rational Mechanics and Analysis, 16, 51-78.

Mishuris, G.S., Movchan, A.B., \& Slepyan, L.I. (2019). Waves in elastic bodies with discrete and continuous dynamic microstructure. Philosophical Transactions of the Royal Society A, 378, 2162. https://doi.org/10.1098/rsta.2019.0313

Nowacki, W. (1986). Theory of Asymmetric Elasticity. Oxford: Pergamon-Press, 383 p.

Nowacki, W.,(1970). Theory of Micropolar Elasticity. Vienna: Springer, 286 p. https://doi.org/10.1007 /978-3-7091-2720-9.

Palmov, V. (1998). Vibrations of Elasto-Plastic Bodies. Berlin, Heidelberg: Springer-Verlag, 311 p.

Pratt, T.L., Horton, J.W., Jr. Muñoz, J., Hough, S.E. Chapman, M.C., \& Olgun, C.G. (2017). Amplification of earthquake ground motions in Washington, DC, and implications for hazard assessments in central and eastern North America. Geophysical Research Letters, 44(24), 12,150-12,160. https://doi.org/10.1002/2017GL075517.

Rezaie, A., Rafiee-Dehkharghani, R., Dolatshahi, K.M., \& Mirghaderi, S.R. (2018). Soil-buried wave barriers for vibration control of structures subjected to vertically incident shear waves. Soil Dynamics and Earthquake Engineering, 109, 312-323. https://doi.org/10.1016/j.soildyn.2018.03.020.

Skurativskyi, S.I. (2014). Chaotic wave solutions in a nonlocal model for media with vibrating inclusions. Journal of Mathematical Sciences, 198(1) 54-61. https://doi.org/10.1007/s10958014-1772-8.

Skurativskyi, S. I., \& Skurativska, I.A. (2018). Dynamics of quasiharmonic wave packets in media with inclusions: Proceedings of international scientific and practical conference "Information Technologies and Computer Modelling» (pp. 242-245). Ivano-Frankivsk. Retrieved from http:// itcm.comp-sc.if.ua/2018/skurativskuj.pdf (in Ukrainian).

Skurativskyi, S.I., Skurativska, I. A., Bukur, G.V., \& Maslova, O.M. (2019). Polynomial solutions of nonlinear system of PDE describing dynamics of complex medium with oscillating inclusions. Transactions of Institute of Mathematics of NAS of Ukraine, 16(1), 155-163 (in Ukrainian) 
Slepjan, L.I. (1967). The wave of deformation in rods with amortized mass. Mechanics of Solids, $5,34-40$.

Smith, W.E.T. (1962). Earthquakes of Eastern Canada and Adjacent Areas, 1534-1927 (pp. 271 301). Publication of the Dominion Observatory, Ottawa 26.

Wolf, J.P. (1985). Dynamic soil-structure interaction. Prentic-Hall, 466 p.

Yoshida, N. (2015). Seismic Ground Response Analysis. Springer, 365 p.

\title{
Оцінка сейсмічної реакції прошарку грунту 3 коливними включеннями
}

\author{
О.В. Кендзера, С.В. Микуляк, Ю.В. Семенова, І.А. Скуратівська, \\ C.I. Скуратівський, 2020
}

Інститут геофізики ім. С.І. Субботіна НАН України, Київ, Україна

\begin{abstract}
Результати сучасних досліджень наслідків землетрусів свідчать про те, що грунтові пласти, розташовані під будівлями та спорудами, можуть суттєво трансформувати сейсмічну хвилю, що проходить через їх товщу, та катастрофічним чином вплинути на ці об'єкти. Тому дослідження хвильових процесів у грунтових масивах є надзвичайно важливими і актуальними. Відомо, що грунти характеризуються значною неоднорідністю, яка впливає на спектральні характеристики сейсмічних хвиль, тому вона повинна враховуватись при аналізі хвильових полів у грунтових пластах. У цій праці запропоновано описувати динаміку неоднорідного грунтового масиву в рамках моделі пружного середовища з осцилюючими невзаємодіючими між собою дисипативними включеннями. Аля такого модельного середовища ставиться крайова задача про вібрацію прошарку скінченної товщини з вільною поверхнею та гармонічним збуренням на його нижньому краї. На основі розв'язку цієї задачі проаналізовано вплив включень на характеристики хвиль. З'ясовано, що власні частоти включень суттєво впливають на передавальну функцію, яка характеризує підсилення зміщень на вільній поверхні відносно зміщень на нижній межі шару: при зростанні власної частоти коливань включень поблизу основного резонансу виділяється додаткова резонансна частота прошарку грунту, а на високих частотах відбувається виродження резонансів. Аля випадку, коли власні частоти включень мають недискретний розподіл з двома виділеними частотами, вплив включень проявляється при низькочастотних коливаннях, а у високочастотному діапазоні зменшується лише резонансні амплітуди. Підхід до аналізу відгуку прошарку грунту на сейсмічні збурення, в якому використовується модель з коливними включеннями, є перспективним для задач сейсмостійкого проєктування та будівництва.
\end{abstract}

Ключові слова: амплітудно-частотна характеристика, резонансні явища, моделі неоднорідних геосередовищ, моделювання реакції грунту на сейсмічні впливи. 


\title{
Оценка сейсмической реакции слоя грунта с колеблющимися включениями
}

\author{
А.В. Кендзера, С.В. Микуляк, Ю.В. Семенова, \\ И.А. Скуратовская, С.И. СкуратовСкий, 2020 \\ Институт геофизики им. С.И. Субботина НАН Украины, \\ Киев, Украина
}

\begin{abstract}
Результаты современных исследований последствий землетрясений свидетельствуют о том, что грунтовые пласты, расположенные под зданиями и сооружениями, могут существенно трансформировать сейсмическую волну, проходящую через их толщу, и катастрофическим образом повлиять на эти объекты. Поэтому исследования волновых процессов в грунтовых массивах чрезвычайно важны и актуальны. Известно, что грунты обладают значительной неоднородностью, влияющей на спектральные характеристики сейсмических волн, поэтому она должна учитываться при анализе волновых полей в грунтовых пластах. В этой работе предложено описывать динамику неоднородного грунтового массива в рамках модели упругой среды с осциллирующими невзаимодействующими между собой диссипативными включениями. Аля такой модельной среды становится краевая задача о вибрации слоя конечной толщины со свободной поверхностью и гармоническим возмущением на его нижнем крае. Опираясь на решение этой задачи, проанализировано влияние включений на характеристики волн. Выяснено, что собственные частоты включений существенно влияют на передаточную функцию, описывающую усиление смещений на свободной поверхности относительно смещений на нижней границе слоя: при увеличении собственной частоты колебаний включений вблизи основного резонанса выделяется дополнительная резонансная частота слоя грунта, а на высоких частотах происходит вырождение резонансов. Аля случая, когда собственные частоты включений имеют недискретное распределение с двумя выделенными частотами, влияние включений проявляется при низкочастотных колебаниях, а в высокочастотной области уменьшаются только резонансные амплитуды. Подход к анализу реакции слоя грунта на сейсмические возмущения, в котором используется модель с колеблющимися включениями, является перспективным для задач сейсмостойкого проектирования и строительства.
\end{abstract}

Ключевые слова: амплитудно-частотная характеристика, резонансные явления, модели неоднородных геосред, моделирование реакции грунта на сейсмические воздействия. 